BULLETIN OF PNRPU. GEOLOGY. OIL \& GAS ENGINEERING \& MINING

ВЕСТНИК ПНИПУ. ГЕОЛОГИЯ. НЕФТЕГАЗОВОЕ И ГОРНОЕ ДЕЛО

ISSN 2224-9923

Volume / Tom 15 №19 2016

http://vestnik.pstu.ru/geo/

УДК 553.982 .2

Article / Статья

(C) PNRPU / ПНИПУ, 2016

\title{
STUDY OF OIL RECOVERY FROM RESERVOIRS OF DIFFERENT VOID TYPES WITH USE OF MULTIDIMENSIONAL STATISTICAL ANALYSIS
}

\section{V.I. Galkin, I.N. Ponomareva, V.A. Repina ${ }^{1}$}

Perm National Research Polytechnic University (29 Komsomolskii av., Perm, 614990, Russian Federation)

${ }^{1}$ PermNIPIneft branch of LUKOIL-Engineering LLC in Perm (29 Sovetskoi Armii st., Perm, 614066, Russian Federation)

\section{ИССЛЕДОВАНИЕ ПРОЦЕССА НЕФТЕИЗВЛЕЧЕНИЯ В КОЛЛЕКТОРАХ РАЗЛИЧНОГО ТИПА ПУСТОТНОСТИ С ИСПОЛЬЗОВАНИЕМ МНОГОМЕРНОГО СТАТИСТИЧЕСКОГО АНАЛИЗА}

\section{В.И. Галкин, И.Н. Пономарева, В.А. Репина ${ }^{1}$}

Пермский национальный исследовательский политехнический университет (614990, Россия, г. Пермь, Комсомольский пр., 29) ${ }^{1}$ Филиал ООО «ЛУКОЙЛ-Инжиниринг» «ПермНИПИнефть» в г. Перми (614066, Россия, г. Пермь, ул. Советской Армии, 29)

Received / Получена: 01.12.2015. Aссерted / Принята: 27.04.2016. Published / Опубликована: 30.06.2016

\section{Key words:}

complex accumulation, naturally fractured reservoirs, pore type reservoir, oil production law, components of development scheme, well interaction analysis, correlation, correlation fields, multidimensional regression analysis, mathematical models, factors forming oil rate in different reservoirs, linear discriminant functions, authenticity of reservoir detection, oil rate formation scenarios, efficiency of pressure maintenance system

\section{Ключевые слова:}

сложнопостроенная залежь, коллектор трещинного типа, коллектор порового типа, закономерности нефтеизвлечения, элемент системы разработки, оценка взаимодействия между скважинами, корреляция, корреляционные поля, многомерный регрессионный анализ, математические модели, факторы, формирующие дебит нефти в различных коллекторах, линейные дискриминантные функции, достоверность распознавания коллекторов, сценарии формирования дебита нефти, эффективность системы поддержания пластового давления.
Oil recovery laws that take into account distribution of reservoirs with different void types within the same accumulation. Carbonate field data of development of Tournaisian-Famennian oil accumulation was used. For comparison purposes data of development of the field with similar oil properties but reservoir of clastic grain rock and pore type were used. One injector and neighbor producers were used as components of applied production scheme. The type of reservoir within one development object was determined by several studies including pressure build-up curve processed by Warren-Root method. At the first stage correlation coefficients between injection and production of neighbor well were calculated. Calculation was done for different time and with assumption, according to which correlation coefficient is a quantitative measure of interactions between two wells. It is determined that use of correlation coefficient for pore reservoirs is significantly differ to the character of its behavior for fracture reservoir type. Multidimensional mathematical models that characterize flooding and allow determining producer's rate were obtained with considered void type. Linear discriminant functions are built with considered void type of reservoir. Analysis of those functions determined that replacement of oil by water in clastic and carbonates porous rocks and carbonate naturally fractured reservoirs follow different scenarios.

Изучены вопросы установления закономерностей осуществления процессов нефтеизвлечения, учитывающих распространение в пределах одной залежи коллекторов с различными видами пустотности. С этой целью привлечены промысловые материалы по разработке турне-фаменской карбонатной залежи нефтяного месторождения, а также для сравнения - данные о разработке залежи нефти со схожими свойствами нефти, но с терригенным гранулярным коллектором порового типа. Для рассмотрения в статье приняты элементы реализованных систем разработки, представляющих собой одну нагнетательную и соседние добывающие скважины. Тип коллектора в пределах элемента разработки принимался по материалам различных исследований, в том числе по кривой восстановления давления, обработанной по методике Уоррена-Рута. На первом этапе решения поставленной задачи рассчитаны значения коэффициентов корреляции между приемистостью нагнетательной скважины и дебитами соседних добывающих для различных моментов времени, при этом расчет производился в предположении, что коэффициент корреляции является численной мерой взаимодействия между двумя скважинами. Установлено, что изменение коэффициента корреляции во времени для поровых коллекторов значительно отличается от характера его же поведения для коллектора трещинного типа. В дальнейшем проведенные исследования позволили получить многомерные математические модели, характеризующие процесс заводнения и позволяющие определять дебиты добывающих скважин, расположенных вблизи очагов нагнетания, с учетом типа пустотности коллектора на рассматриваемом участке залежи. Анализ линейных дискриминантных функций, построенных с учетом типа пустотности коллектора, позволил установить, что процесс вытеснения нефти водой в терригенных поровых, карбонатных поровых и карбонатных трещинных коллекторах происходит по различным сценариям.

Vladislav I. Galkin (Author ID in Scopus: 55418067700) - Doctor of Geological and Mineralogical Sciences, Professor at the Department of Oil and Gas Geology (tel.: +007 21980 17, e-mail: vgalkin@pstu.ru).

Inna N. Ponomareva (Author ID in Scopus: 36242312300) - PhD in Engineering, Associate Professor, Associate Professor at the Department of Oil and Gas Technologies (mob. tel.: +007 91948384 30, e-mail: pin79@yandex.ru). The contact person for correspondence.

Vera A. Repina - Engineer of $1^{\text {st }}$ category of Hydrodynamic Modeling Department (mob. tel.: +007 902809 63 88, e-mail: Silajcheva.v@yandex.ru).

Галкин Владислав Игнатьевич - доктор геолого-минералогических наук, профессор, заведующий кафедрой геологии нефти и газа (тел.: +007 219 80 17, e-mail: vgalkin@pstu.ru).

Пономарёва Инна Николаевна - кандидат технических наук, доцент, доцент кафедры нефтегазовых технологий (моб. тел.: +007 9194838430 , e-mail: pin79@yandex.ru). Контактное лицо для переписки.

Репина Вера Андреевна - инженер 1-й категории отдела гидродинамического моделирования (моб. тел.: +007 902 809 63 88, e-mail: Silajcheva.v@yandex.ru). 


\section{Introduction}

A zone of reservoirs of pore and fracture type is a key feature of a number of TournaisianFamennian oil formations in Perm region. That was obtained by researches [1, 2]. Features of reservoirs this kind are described in papers [3, 4]. Based on the results of pressure build-up curves processing in accordance with Warren-Root method that is described in papers [5-12] it was determined that zones of fracture reservoirs are directed from southwest to north-east. These zones complicate geological structure of accumulation and development processes. Evaluation of the efficiency of pressure maintenance system and determination of replacement processes of oil by water depending on reservoir void type are on the front burner. Significant volume of field data allows using mathematical statistics in order to overcome this challenge [13].

This paper describes study of mentioned challenge with use of units of field development that represent one injection and neighbor production wells. Each of the units is located in different void type reservoirs. Injector Well 1 is located within carbonate reservoirs of fracture type. Injector Well 2 is located within carbonate reservoirs of pore type. Data on clastic reservoirs of pore type are involved in the study of probability laws of oil replacement processes. An injector Well 3 is located within that reservoir. Oil of clastic and carbonate reservoirs has similar composition and properties.

\section{Mathematical modeling and analysis of interac- tion between producers and injectors}

For all units of field development selected to study following data were obtained: volume of injected water $\left(V_{\mathrm{H}_{2} \mathrm{O}}\right)$, injectability of injectors $(\mathrm{Pr})$ and oil rates of producers $\left(Q_{0}\right)$.

Correlation links between injected water volume and injectability of injectors are:

$$
\begin{aligned}
& \text { Well } 1-\operatorname{Pr}=23.5+0.0293 V_{\mathrm{H}_{2} \mathrm{O}} \text { at } r=0.92 \\
& \text { Well } 2-\operatorname{Pr}=34.6+0.0228 V_{\mathrm{H}_{2} \mathrm{O}} \text { at } r=0.87 \\
& \text { Well } 3-\operatorname{Pr}=12.8+0.0301 V_{\mathrm{H}_{2} \mathrm{O}} \text { at } r=0.90
\end{aligned}
$$

That shows $V_{\mathrm{H}_{2} \mathrm{O}}$ and $\operatorname{Pr}$ correlate quite well. Accumulated injectability $\mathrm{Pr}^{n}$ is involved into analysis. Table 1 shows models of change of $\mathrm{Pr}^{n}$ with time $(t)$.

Table 1 - Dependency of $\operatorname{Pr}^{n}$ on $t$

\begin{tabular}{|c|l|c|}
\hline Well & \multicolumn{1}{|c|}{ Regression equation } & $\begin{array}{c}\text { Coeffi- } \\
\text { cient } R^{2}\end{array}$ \\
\hline 1 & $\begin{array}{l}\operatorname{Pr}^{n}=242.8-0.0006 t^{5}+0.001 t^{4}-0.187 t^{3}+ \\
+11.04 t^{2}-57.74 t\end{array}$ & 0.99 \\
\hline 2 & $\operatorname{Pr}^{n}=-916.1+0.005 t^{3}-1.884 t^{2}+295.4 t$ & 0.99 \\
\hline 3 & $\operatorname{Pr}^{n}=16.26+0.402 t^{2}+84.06 t$ & 0.99 \\
\hline
\end{tabular}

Analysis of dependency data presented in the table 1 show that for Well 1, located in the zone of naturally fractured reservoirs $\operatorname{Pr}^{n}$ changes in accordance with more complicated law, than for Wells 2 and 3 located in pore type reservoirs.

In order to determine influence of injected water on average day oil rates $Q_{0}$ correlation coefficients $r$ between $V_{\mathrm{H}_{2} \mathrm{O}}, \operatorname{Pr}, \operatorname{Pr}^{n}$ and $Q_{0}$ were calculated. It is supposed that based on $r$ values it is possible to evaluate influence of injected in an injector well water on oil rates of producers. At the first stage $r$ was determined for 3-months period from start of injection. Then $r$ was calculated further for 1 month.

Let us have a look on $r$ values change in three producers located in different reservoirs zones. Analysis is performed with use of $Q_{0}$ data from the producers located nearby.

For Well 1 analysis is done based on 5 neighbor producers which are located in naturally fractured reservoirs. For Well 27 neighbor producers located in pore-type reservoir. Analysis of Well 3 is performed based on data of 4 neighbor producers located in pore-type reservoir; rocks are presented by clastic sediments. The space between injectors and producers is varying in the range of 334 to $960 \mathrm{~m}$. Maximum difference in $r$ values during time change is observed at $r\left(\operatorname{Pr}^{n}-Q_{0}\right)$. Thus, typical curves of $r\left(\operatorname{Pr}^{n}-Q_{0}\right)$ change for three producers are look like it is presented on Fig. 1.

Analysis of diagram given in Fig. 1 shows that change of $r$ between $\operatorname{Pr}^{n}$ and $Q_{0}-r\left(\operatorname{Pr}^{n}-Q_{0}\right)$ for wells of interest are unique. It has to be noted, 


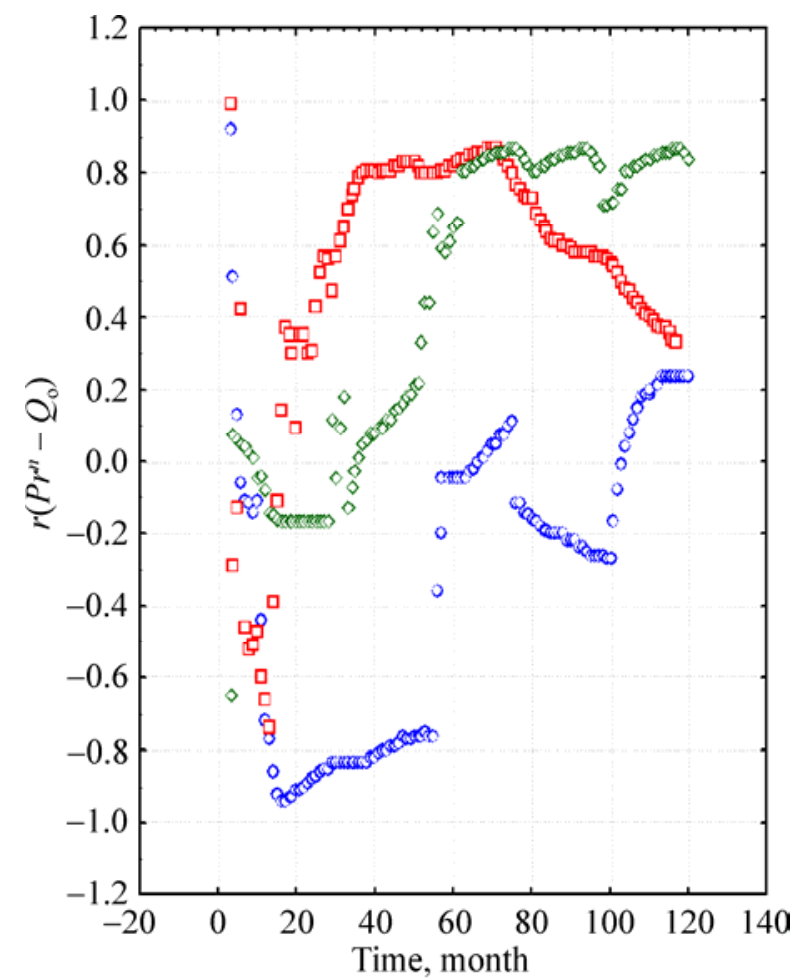

- Fractured carbonates

$\square$ Pore carbonates

$\diamond$ Pore sanstones

Fig. 1. Change of $r$ coefficient between $\operatorname{Pr}^{n}$ and $Q_{0}$ in time for producers

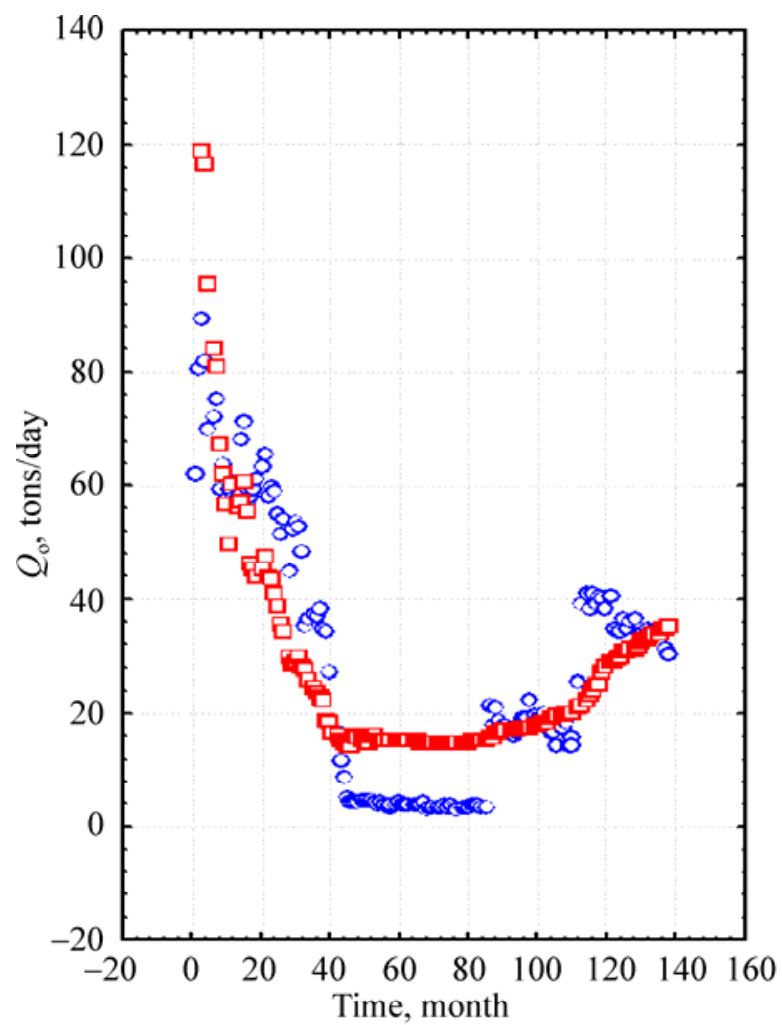

a

-Actual values of oil rate differences presented by change curves $r\left(\operatorname{Pr}^{n}-Q_{0}\right)$ in time for pore carbonate and pore clastic reservoirs are significantly smaller than differences presented by curves which characterize pore and naturally fractured reservoirs. The same calculation of $r$ was done between $V_{\mathrm{H}_{2} \mathrm{O}}$ and $Q_{\mathrm{o}}-r\left(\operatorname{Pr}-Q_{\mathrm{o}}\right)$ and between $V_{\mathrm{H}_{2} \mathrm{O}}$ and $\mathrm{Pr}-\mathrm{Q}_{\mathrm{o}}-r\left(\mathrm{Pr}-\mathrm{Q}_{\mathrm{o}}\right)$.

To account complex influence of coefficients $r$ on $Q_{0}$ multidimensional regression analysis is used. Average current oil rate $Q_{0}$ is a function of following factors: $r\left(V_{\mathrm{H}_{2} \mathrm{O}}-P r\right), r\left(P r-Q_{0}\right), r\left(\operatorname{Pr}^{n}-Q_{0}\right)$. For instance, multidimensional model of producer, located in naturally fractured reservoir is

$$
\begin{gathered}
Q_{0}^{m}=-124.337 r\left(V_{\mathrm{H}_{2} \mathrm{O}}-P r\right)- \\
-1.719 r\left(\operatorname{Pr}-Q_{\mathrm{o}}\right)+57.033 r\left(\operatorname{Pr}^{n}-Q_{0}\right)+ \\
+182.540
\end{gathered}
$$

if $R=0,85, p<0,0000$, forecast error is 6,1 tons/day. Values of $Q_{0}^{m}$ were calculated by mentioned formula. Graphical comparison of $Q_{0}$ and $Q_{0}^{m}$ in time is presented in Fig. 2, $a$.

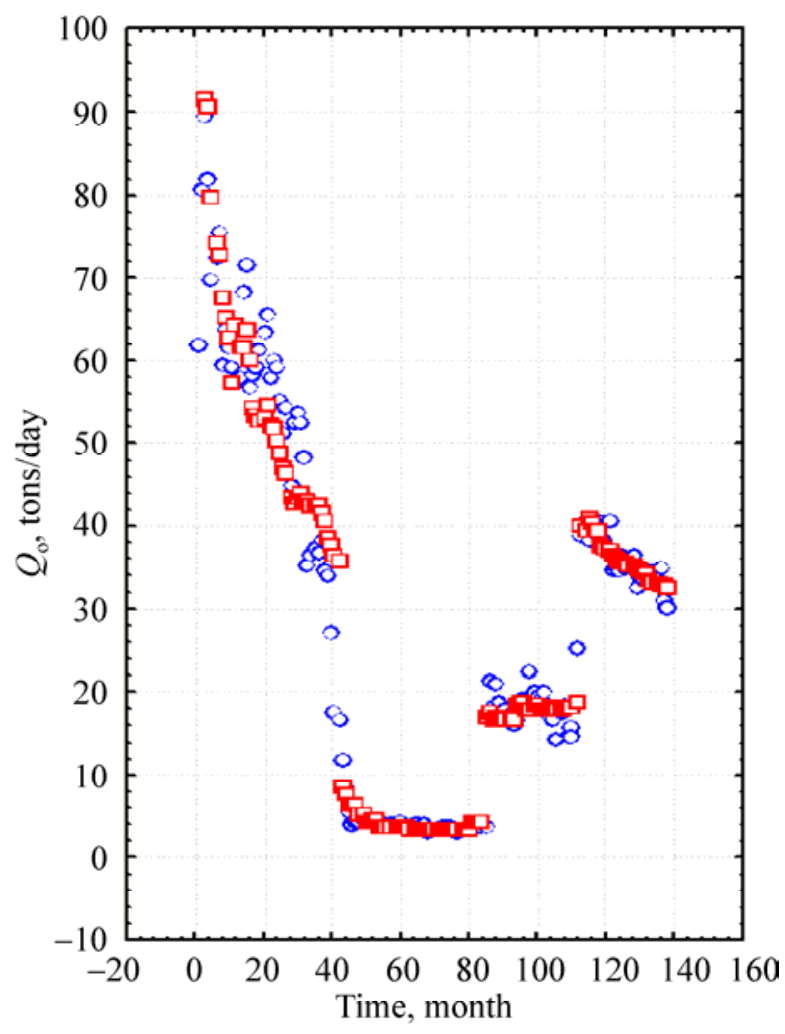

$b$

$\square$ Model values of oil rate

Fig. 2. Change of $Q_{0}$ and $Q_{0}^{m}$ in time: $a$-multidimensional model; $b$-multidimensional time model 
Analysis of Fig. 2, a shows there are 4 sections within the graph. First section is in the rage of 0 to 42 months and values $Q_{0}^{m}$ correlate well. For the second section if $43<t<84$ months then $Q_{0}^{m}$ exceeds $Q_{0}$. Then $Q_{\text {о и }} Q_{0}^{m}$ correlate poor, but in this range there are 2 more subsections. Third section is in the range of 85 to 112 months; fourth is within a range of 113 to 138 months. To account a ratio of $Q_{0}$ and $Q_{0}^{m}$ in the same time frames as in Fig. 2, $a$, multidimensional models are built.

\section{Multidimensional mathematical time modeling and analysis of interaction between producers and injectors}

Time multidimensional models for determination of oil rates $Q_{0}^{m t}$ by an injector, located in naturally fractured reservoir are shown in table 2 .

Table 2 shows that formation of model values $Q_{0}^{m t}$ in time is appeared to be different. That is proved by coefficients $r$ and values of absolute terms of regression equation. Note, that in the range of 85-112 months the model is characterized by statistically negligible criteria.
Values of $Q_{0}^{m}$ were calculated by 138 values.

Comparison of $Q_{0}$ and $Q_{0}^{m}$ in time is presented on Fig. 2, $b$. Analysis shows $Q_{0}$ and $Q_{0}^{m}$ are equal in general. Note, there is low correlation between $Q_{0}$ and $Q_{0}^{m}$ in time frame of 85-112 months that is quantitatively proved by $r$ values, given in the Table 2. Based on calculation results, performed by common and time models for this producer correlation fields between $Q_{0}$ and $Q_{0}^{m}, Q_{0}$ and $Q_{0}^{m t}$ are built (Fig. 3).

Correlation fields between values of $Q_{0}^{m}$, calculated by common model and values of $Q_{0}^{m t}$, calculated by time models with actual oil rates $Q_{0}$, are slightly different in terms of correlation link (Fig. 3). First case: $r=0.86$, second one: $r=0.98$.

Authors suggest a hypothesis that value of $Q_{0}^{m}$, calculated by the common data is in charge of oil rated formation due to water injection. Values of $Q_{0}^{m t}$ are formed by water injection and other techniques (they are not a subject of this article) of reservoir stimulation

Table 2 - Models to calculate $Q_{0}^{m t}$

\begin{tabular}{|c|c|c|c|c|c|}
\hline \multirow{2}{*}{$\begin{array}{l}\text { Time frame, } \\
\text { month }\end{array}$} & \multicolumn{3}{|c|}{$\frac{\text { Coefficients of base }}{p}$} & \multirow{2}{*}{$\frac{\text { Absolute term }}{p}$} & \multirow{2}{*}{$\frac{R}{p}$} \\
\hline & $r\left(V_{\mathrm{H}_{2} \mathrm{O}}-P r\right)$ & $r\left(P r-Q_{0}\right)$ & $r\left(\operatorname{Pr}^{n}-Q_{0}\right)$ & & \\
\hline $0-42$ & $\frac{-81.2298}{0.021634}$ & $\frac{6.5303}{0.495413}$ & $\frac{31.6133}{0.000000}$ & $\frac{144.339}{0.000026}$ & $\frac{0.871}{0.00000}$ \\
\hline $43-84$ & $\frac{-34.4540}{0.469092}$ & $\frac{-0.7467}{0.528889}$ & $\frac{94.1672}{0.001472}$ & $\begin{array}{l}125.0308 \\
0.069976\end{array}$ & $\frac{0.815}{0.0000}$ \\
\hline 85-112 & $\frac{282.870}{0.491273}$ & $\frac{-101.588}{0.631770}$ & $\frac{50.634}{0.660733}$ & $\frac{-199.380}{0.567275}$ & $\frac{0.206}{0.78420}$ \\
\hline 113-138 & $\frac{170.859}{0.285989}$ & $\frac{64.840}{0.529289}$ & $\frac{-27.324}{0.180338}$ & $\frac{-137.853}{0.357782}$ & $\frac{0.842}{0.00000}$ \\
\hline
\end{tabular}

The foregoing allows evaluating the influence of injected volume of water on oil rates through the calculation of differential parameter $d Q$ by following formula:

$$
d Q=\left(Q_{0}^{m t}-Q_{0}^{m}\right) / Q_{0}^{m t} .
$$

Change of $d Q$ for wells of interest in all the cases is unique.
For Well 1 based on the calculations, performed by common and time models, comparison of $Q_{0}$ and $Q_{0}^{m}$ is performed including 5 neighbor producers (Fig. 4, a).

Correlation links between $Q_{0}^{m}$ values, calculated by common models and actual oil rated $Q_{0}(r=0.69, p=0.000)$ is much weak, than 


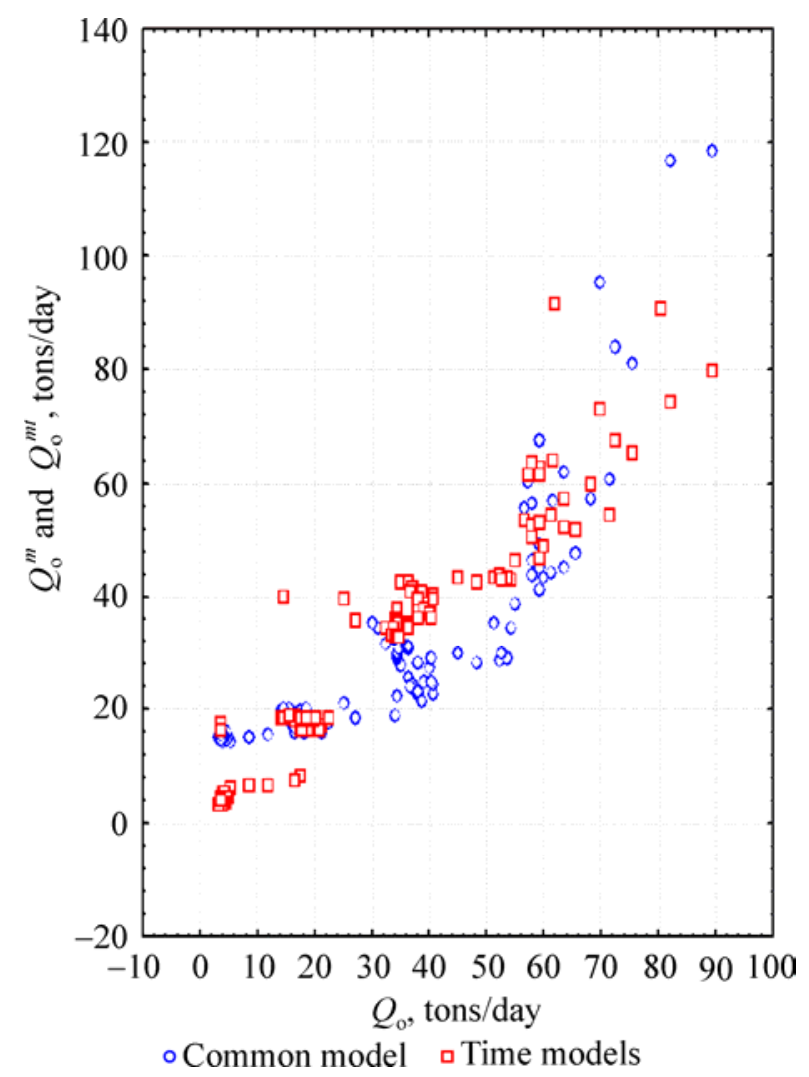

Fig. 3. Correlation fields

between $Q_{0}^{m t}$, calculated though differential models, and $Q_{o}(r=0.99, p=0.000)$. The equation of regression between $Q_{0}$ и $Q_{0}^{m}$, calculated by common models is

$$
Q_{0}=9.932+0.860 Q_{0}^{m} .
$$

Equation of regression between $Q_{\text {о и }} Q_{0}^{m t}$, calculated by differential models, is

$$
Q_{0}=-0.001+0.999 Q_{0}^{m t} .
$$

Analysis of correlation coefficients and regression equations shows that second equation describes the process of formation of $Q_{0}$ values for 5 producers.

In order to compare average values of $Q_{0}^{m}$ and $Q_{0}$ for each well $t$-statistics is used. Calculation results are presented in Table 3 (calculation is done on the injection Well 1).

Analysis of results shows that for average values there is a statistical correlation between $Q_{0}$ and $Q_{0}^{m}$ for wells $1 d, 2 d, 3 d$ and $4 d$. For $5 d$ well aver- age value of $Q_{0}$ and $Q_{0}^{m}$ are statistically different. For injection wells 2 and 3 calculation is done in the same way.

Values of $Q_{0}$ and $Q_{0}^{m}$ are compared based on the calculation of common time models for the injection Well 2 using 7 producers (Fig. 4, b).

Results on the Fig. 4, $b$ prove that correlation in the first case ( $r=0.72, p=0.000)$ is slightly less, than in the second one $(r=0.81, p=0.000)$.

In accordance with calculation of common and time models for the injector 3 , located in pore-type clastic reservoir comparison of $Q_{0}$ and $Q_{0}^{m}$ is done using 4 producers (Fig. 4. $c$ ).

First case correlation $(r=0.69, p=0.000)$ is slightly less, than second one $(r=0.78, p=0.000)$. Comparison of correlation fields, presented in Fig. 4 shows that they are different to each other based on analysis of actual and model oil rates, obtained by common and differential models. Strong difference in correlation fields is observed between the values of model and actual oil rates, obtained influence of injector 1 (naturally fractured reservoir). For wells of pore-type reservoirs model and actual values of oil rate are less obvious (wells 2, 3).

Comparison of average values of parameters in different reservoir zones in accordance with $t$-criteria is presented in Table 4.

In the average values of the Table 3 statistical differences is observed only for $d Q$ value obtained during the analysis of 3 injectors.

\section{Use of discriminant analysis to study features of flooding of reservoirs with different void type}

At the final stage of analysis of influence of $r\left(V_{\mathrm{H}_{2} \mathrm{O}}-P r\right), r\left(\operatorname{Pr}-Q_{\mathrm{o}}\right), r\left(\operatorname{Pr}^{n}-Q_{\mathrm{o}}\right), Q_{0}^{m}, Q_{0}^{m t}, d Q$ values, determined for different reservoir types, on oil rates discriminant analysis is used. A method is based on construction of linear discriminant functions (LDF) [14, 15]. During construction of LDF трещинные naturally fractured carbonate reservoirs have higher values of mentioned above 

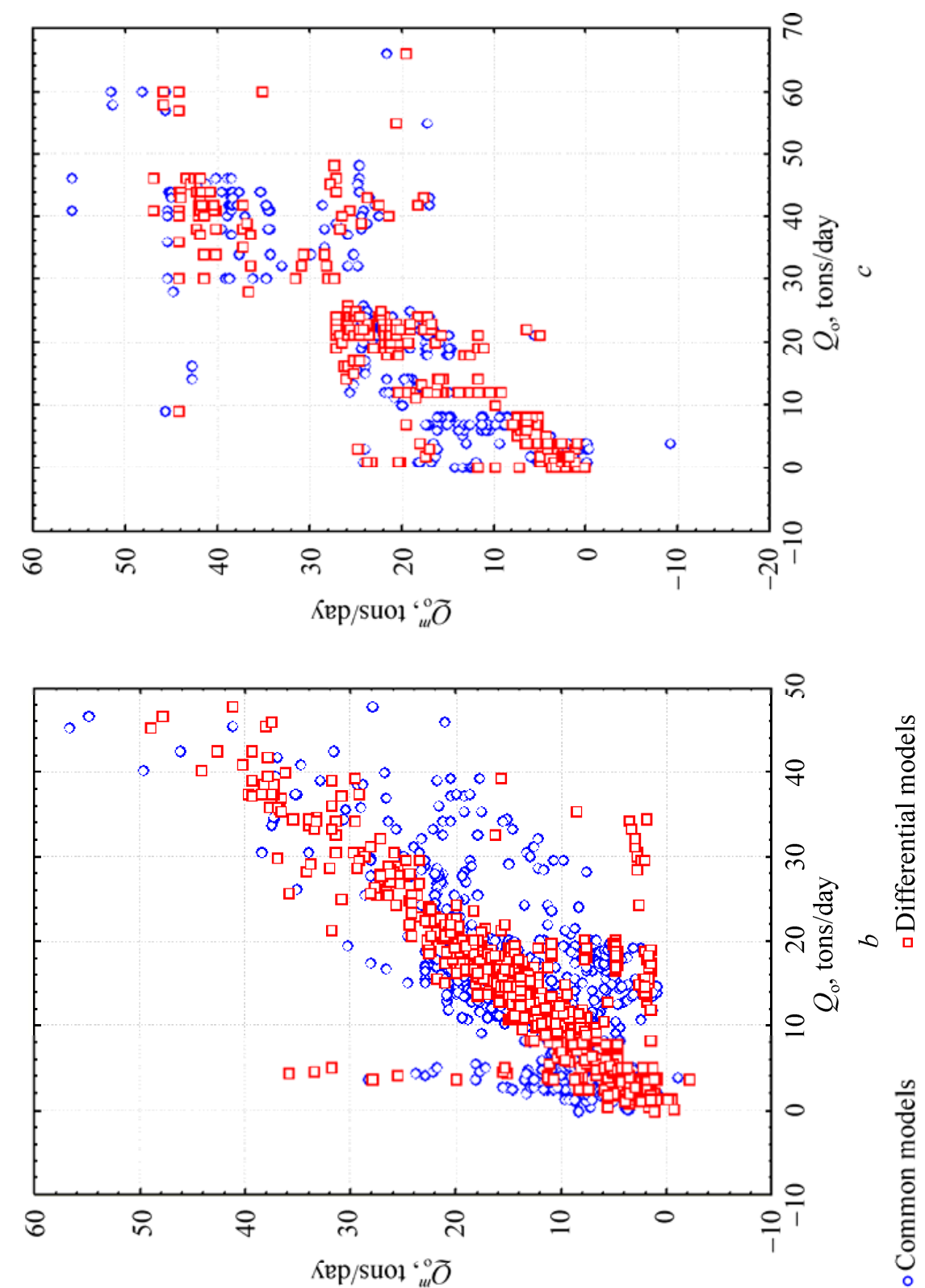

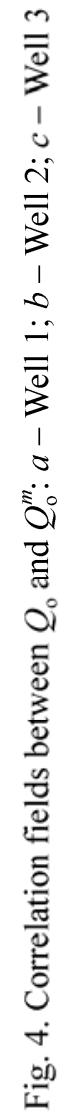

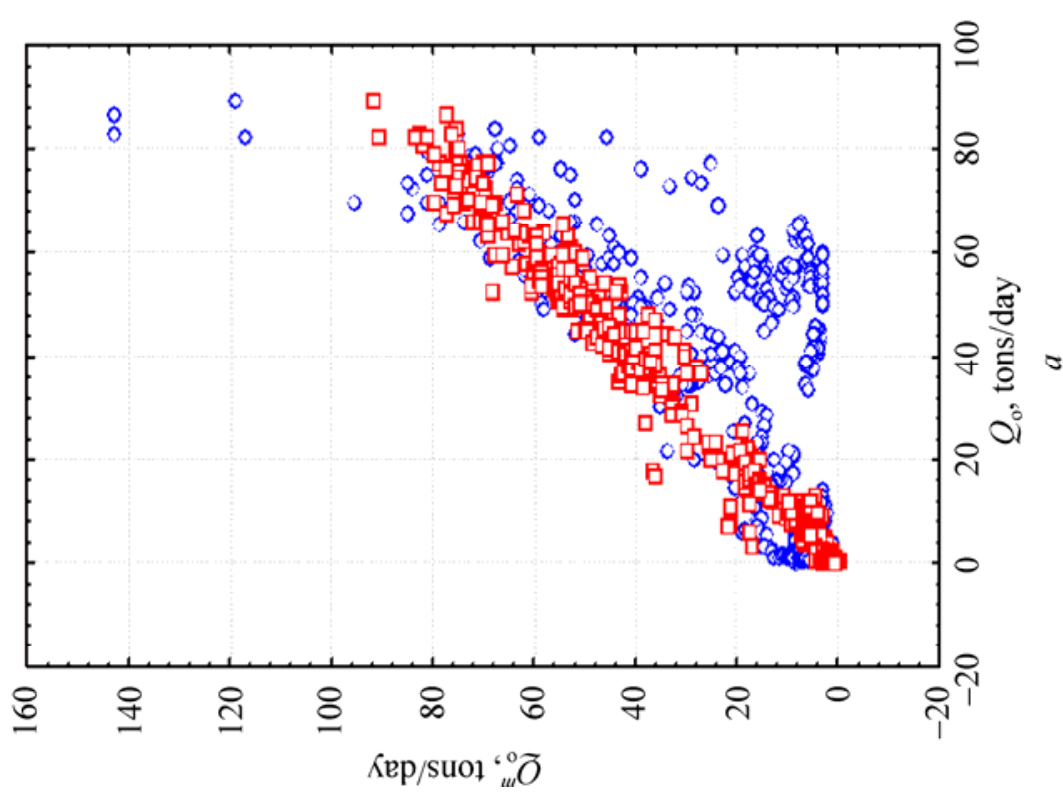


Table 3 - Comparison of average values of $Q_{0}$ and $Q_{0}^{m}$

\begin{tabular}{|c|c|c|c|c|c|}
\hline Neighbor producers & $Q_{0}$, tons/day & $\begin{array}{c}Q_{0}^{m c}, \text { tons/day } \\
\text { (common model) }\end{array}$ & $\begin{array}{l}Q_{0}^{m t}, \text { tons/day } \\
\text { (time models) }\end{array}$ & $\frac{t^{m c}}{p}$ & $\frac{t^{m t}}{p}$ \\
\hline $1 d$ & $28.3 \pm 22.6$ & $27.6 \pm 18.9$ & $28.7 \pm 22.6$ & $\begin{array}{l}\frac{0.25076}{0.802186} \\
\end{array}$ & $\begin{array}{r}0.05076 \\
0.902186\end{array}$ \\
\hline $2 \mathrm{~d}$ & $18.3 \pm 19.4$ & $17.8 \pm 18.3$ & $17.9 \pm 18.5$ & $\frac{0.21526}{0.829729}$ & $\underline{0.211665}$ \\
\hline $3 d$ & $2.4 \pm 3.2$ & $2.3 \pm 1.1$ & $2.3 \pm 2.7$ & $\underline{0.081919}$ & $\underline{0.066063}$ \\
\hline $4 \mathrm{~d}$ & $19.3 \pm 26.5$ & $18.4 \pm 23.3$ & $18.4 \pm 25.3$ & $\begin{array}{l}0.295935 \\
0.767506\end{array}$ & $\underline{0.285291}$ \\
\hline $5 d$ & $56.2 \pm 11.4$ & $18.4 \pm 23.3$ & $56.2 \pm 10.9$ & $\underline{17.12945}$ & $\begin{array}{l}0.011606 \\
0.990748\end{array}$ \\
\hline
\end{tabular}

Table 4 - Comparison of average parameter by well

\begin{tabular}{|c|c|c|c|c|c|c|}
\hline \multirow[t]{2}{*}{ Parameter } & \multicolumn{3}{|c|}{ Well } & \multicolumn{3}{|c|}{$\frac{t}{p}$} \\
\hline & 1 & 2 & 3 & Well 1-2 & Well 1-3 & Well 2-3 \\
\hline$r\left(V_{\mathrm{H}_{2} \mathrm{O}}-P r\right)$ & $0.91 \pm 0.02$ & $0.91 \pm 0.02$ & $0.91 \pm 0.02$ & $\begin{array}{c}\underline{0.307} \\
0.7586\end{array}$ & $\frac{0.353}{0.7237}$ & 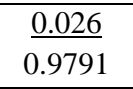 \\
\hline$r\left(P r-Q_{0}\right)$ & $-0.26 \pm 0.24$ & $-0.09 \pm 0.17$ & $-0.29 \pm 0.30$ & $\frac{-6.171}{0.0000}$ & $\begin{array}{c}\frac{1.014}{0.3109} \\
\end{array}$ & $\frac{6.411}{0.0000}$ \\
\hline$r\left(\operatorname{Pr}^{n}-Q_{o}\right)$ & $-0.70 \pm 0.38$ & $-0.67 \pm 0.40$ & $-0.57 \pm 0.41$ & $\frac{-0.705}{0.4809}$ & $\frac{-2.918}{0.0037}$ & $\begin{array}{l}-1.986 \\
0.0479\end{array}$ \\
\hline$Q_{o}^{m}$, tons/day & $28.3 \pm 19.4$ & $14.4 \pm 21.3$ & $5.4 \pm 6.8$ & $\frac{5.043}{0.00000}$ & $\frac{6.140}{0.00000}$ & $\frac{1.005}{0.3156}$ \\
\hline$Q_{0}^{m t}$, tons/day & $28.1 \pm 21.5$ & $16.3 \pm 18.9$ & $5.6 \pm 23.1$ & $\frac{4.576}{0,00000}$ & $\frac{5.576}{0.00000}$ & $\frac{0.877}{0.3810}$ \\
\hline$d Q$ & $-0.79 \pm 1.45$ & $-0.39 \pm 0.71$ & $-2.197 \pm 0.81$ & $\frac{-2.6828}{0.0077}$ & $\frac{-4.193}{0.00000}$ & $\frac{5.124}{0.0000}$ \\
\hline
\end{tabular}

parameters that are calculated by models with closest producers. Here, relationship between them and injector 1 is evaluated. Pore carbonate reservoirs obtained from closest producers are used in the model. The subject of study is influence of injector 2 is analysed. Pore reservoirs of sandstones represent modeling data, obtained by 4 producers, located nearby injector 3 .

Based on these data following LDF were constructed:

$$
\begin{aligned}
Z_{1}= & 12.1046 r\left(V_{\mathrm{H}_{2} \mathrm{O}}-P r\right)-0.03597 r\left(\operatorname{Pr}-Q_{0}\right)- \\
& -0.23894 r\left(\operatorname{Pr}^{n}-Q_{0}\right)-0.00209 Q_{0}^{m}+ \\
& +0.01268 Q_{0}^{m t}-0.06982 d Q-8.55129
\end{aligned}
$$

if $R=0.970, \chi^{2}=6726,37, p=0.000000$;

$$
\begin{aligned}
Z_{2}= & 0.856605 r\left(V_{\mathrm{H}_{2} \mathrm{O}}-P r\right)+2.406087 r\left(\operatorname{Pr}-Q_{0}\right)+ \\
& +1.270443 r\left(\operatorname{Pr}^{n}-Q_{0}\right)+0.029147 Q_{0}^{m}- \\
& -0.069647 Q_{0}^{m t}+0.29827 d Q+0.686364
\end{aligned}
$$

if $R=0.718, \chi^{2}=1366.184, p=0.000000$.

Based on these functions $Z_{1}$ and $Z_{2}$ (presented in Fig. 5) were calculated.

Fig. 5 shows that values of $Z_{1}$ and $Z_{2}$ are distinguished quite well within reservoir groups that are studied. Average value of $Z_{1}$ for naturally fractured reservoirs equals to +3.034 , for pore carbonate reservoirs equals to +2.156 , for pore sandstones equals to -6.338 . Average value of $Z_{2}$ for naturally fractures reservoirs equals to -1.318 , for pore carbonate reservoirs equals to -1.133 , for pore sandstones equals to $-0,148$. Authenticity of reservoir 


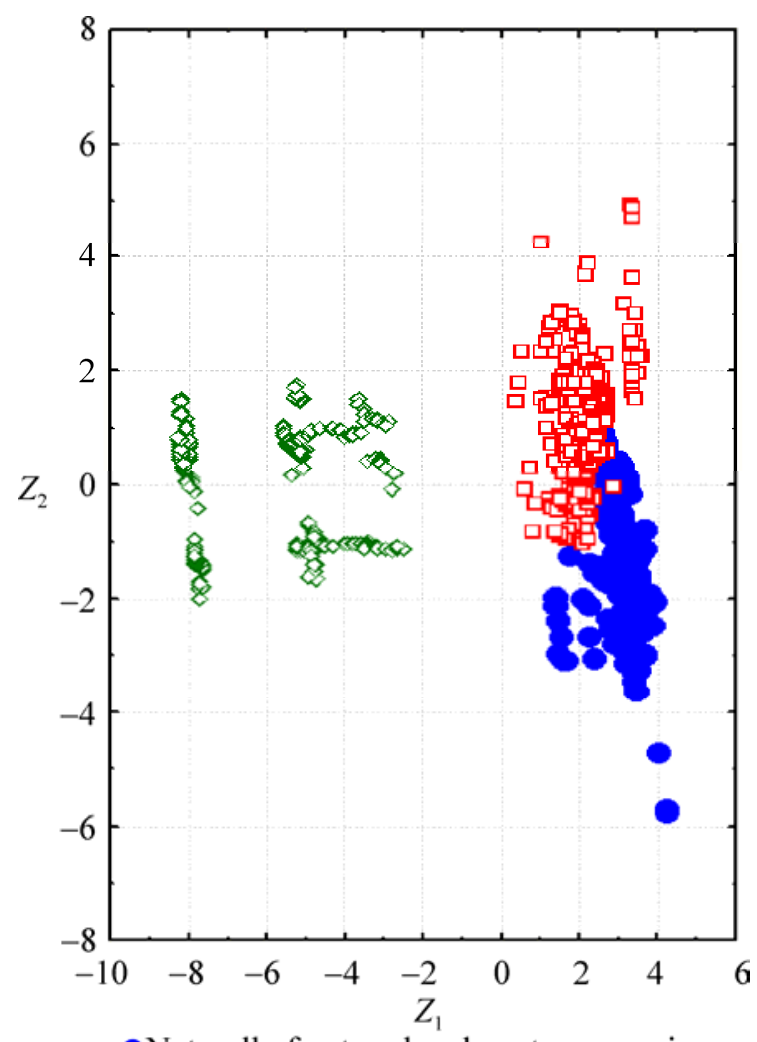

- Naturally fractured carbonate reservoirs $\square$ Carbonate reservoirs of pore type $\diamond$ Sandstone reservoirs of pore type

Fig. 5. Distribution of $Z_{1}$ and $Z_{2}$ values for different void type reservoirs

identification for naturally fractures carbonates is $83.5 \%$, pore type carbonates $-96.4 \%$ and pore sandstones $-100.0 \%$. This shows that influence of injectors 1-3 on producer's oil rate is characterized by different values of criteria, chosen for analysis. Thus, it can be stated that water injection and oil replacement for studied reservoirs form different scenarios of oil rate. Therefore, in the analysis of pressure maintenance system efficiency for different reservoirs it has to be taken into account.

\section{Conclusion}

1. In presence of reservoirs of both pore and fracture types within the same accumulation replacement of oil by water has to be studied differentially for each accumulation zone.

2. To overcome challenges of TournaisianFamennian accumulation development multidimensional mathematical models are obtained. Models characterize flooding processes and allow to evaluate oil rate of producers, located nearby injection heart with considered void type of reservoir zone.

3. Analysis of linear discriminant functions, built with considered reservoir void type, allowed determining that oil rate and replacement of oil by water in porous clastic, porous carbonate and naturally fractured carbonate reservoirs are different for each scenario.

\section{References}

1. Mitrofanov V.P., Zlobin A.A. Ostatochnaia neftenasysh-chennost' i osobennosti porovogo prostranstva karbonatnykh porod [Residual oil saturation and features of pore space of carbonate rocks]. Perm': PermNIPIneft branch of LUKOIL-Engineering LLC in Perm, 2003. 240 p.

2. Denk S.O. Problemy treshchinovatykh produktivnykh obektov [Challenges of naturally fractured reservoirs]. Perm': Elektronnye izdatel'skie sistemy, 2004. 334 p.

3. Cherepanov S.S. Kompleksnoe izuchenie treshchinovatosti karbonatnykh zalezhei metodom Uorrena-Ruta s ispol'zovaniem dannykh seismofatsial'nogo analiza (na primere turne-famenskoi zalezhi Ozernogo mestorozhdeniia) [Integrated research of carbonate reservoir fracturing by Warren-Root method using seismic facies analysis (evidence from Tournaisian-Famennian deposit of Ozernoe field)]. Bulletin of PNRPU. Geology. Oil \& Gas Engineering \& Mining, 2015, no.14, pp.6-12. DOI: 10.15593/2224-9923/2015.14.1.

4. Galkin V.I., Ponomareva I.N., Cherepanov S.S. Razrabotka metodiki otsenki vozmozhnostei vydeleniia tipov kollektorov po dannym krivykh vosstanovleniia davleniia po geologo-promyslovym kharakteristikam plasta [Development of the methodology for evaluation of possibilities to determine reservoir types based on pressure buildup curves, geological and reservoir properties of the formation (case study of Famennian deposits of Ozernoe field)]. Bulletin of PNRPU. Geology. Oil \& Gas Engineering \& Mining, 2015, no.17, pp. 32-40. DOI: 10.15593/2224-9923/2015.17.4. 
5. Cherepanov S.S., Martiushev D.A., Ponomareva I.N. Otsenka fil'tratsionno-emkostnykh svoistv treshchinovatykh karbonatnykh kollektorov mestorozhdenii Predural'skogo kraevogo progiba [Evaluation of the petrophysical and reservoir properties of carbonate reservoirs of the Upper Kama region on full-size core samples]. Neftyanoe Khozyaistvo Oil Industry, 2013, no.3, pp.62-65.

6. Tiab Dzh., Donaldson E.Ch. Petrofizika: teoriia i praktika izucheniia kollektorskikh svoistv gornykh porod i dvizheniia plastovykh fliuidov [Petrophysics: theory and practice of study of reservoir properties of rocks and reservoir fluid movement]. Perevod s angliiskogo. Moscow: Premium Inzhiniring, 2009. 868 p.

7. Houze O., Viturat D., Fjaere O.S. Dinamic data analysis. Paris: Kappa Engineering, 2008. 694 p.

8. Warren J.E., Root P.J. The behavior of naturally fractured reservoirs. Soc. Petrol. Eng. J., 1963, vol.3, is.3, pp.245-255. DOI: 10.2118/426-PA.

9. Tiab D. Modern core analysis. Vol. 1. Theory, core laboratories. Houston, Texas, 1993. 200 p.

10. Van Golf-Racht T.D. Fundamentals of fractured reservoir engeneering. AmsterdamOxford-New York: Elsevier scientific publishing company, 1982. 709 p.

11. Horne R.N. Modern well test analysis: A computer Aided Approach. 2nd ed. Palo Alto: Petroway Inc, 2006. 257 p.
12. Cherepanov S.S., Ponomareva I.N., Erofeev A.A., Galkin S.V. Opredelenie parametrov treshchinovatosti porod na osnove kompleksnogo analiza dannykh izucheniia kerna, gidrodinamicheskikh i geofizicheskikh issledovanii skvazhin [Determination of fractured rock parameters based on a comprehensive analysis of the data core studies, hydrodynamic and geophysical well tests]. Neftyanoe Khozyaistvo - Oil Industry, 2014, no.2, pp.94-96.

13. Johnson N.L., Leone F.C. Statistics and experimental design. New York-London-SydneyToronto, 1977. $606 \mathrm{p}$.

14. Putilov I.S. Razrabotka tekhnologii kompleksnogo izucheniia geologicheskogo stroeniia i razmeshcheniia mestorozhdenii nefti i gaza [Development of technologies for a comprehensive study of of geological structure and location of oil and gas fields] Perm': Izdatel'stvovo Permskogo natsional'nogo issledovatel'skogo politekhnicheskogo universiteta, 2014. 285 p.

15. Putilov I.S., Galkin V.I. Primenenie veroiatnostnogo statisticheskogo analiza dlia izucheniia fatsial'noi zonal'nosti turne-famenskogo karbonatnogo kompleksa Sibirskogo mestorozhdeniia [Use of probabilistic statistical analysis for the study of facies zonation of Tournaisian-Famennian carbonate complex of Siberian field]. Neftyanoe Khozyaistvo - Oil Industry, 2007, no.9, pp.112-114.

\section{Список литературы}

1. Митрофанов В.П., Злобин А.А. Остаточная нефтенасыщенность и особенности порового пространства карбонатных пород / Филиал ООО «ЛУКОЙЛ-Инжиниринг» «ПермНИПИнефть» в г. Перми. - Пермь, 2003. - 240 с.

2. Денк С.О. Проблемы трещиноватых продуктивных объектов. - Пермь: Электронные издательские системы, 2004. - 334 с.

3. Черепанов С.С. Комплексное изучение трещиноватости карбонатных залежей методом Уоррена-Рута с использованием данных сейсмофациального анализа (на примере турнефаменской залежи Озерного месторождения) // Вестник Пермского национального исследовательского политехнического университета. Геология. Нефтегазовое и горное дело. - 2015. - № 14. C. 6-12. DOI: 10.15593/2224-9923/2015.14.1.

4. Галкин В.И., Пономарева И.Н., Черепанов С.С. Разработка методики оценки возможностей выделения типов коллекторов по данным кривых восстановления давления по геологопромысловым характеристикам пласта // Вестник Пермского национального исследовательского политехнического университета. Геология. Нефтегазовое и горное дело. - 2015. - № 17. C. 32-40. DOI: 10.15593/2224-9923/2015.17.4.

5. Черепанов С.С., Мартюшев Д.А., Пономарева И.Н. Оценка фильтрационно- 
емкостных свойств трещиноватых карбонатных коллекторов месторождений Предуральского краевого прогиба // Нефтяное хозяйство. 2013. - № 3. - С. 62-65.

6. Тиаб Дж., Доналдсон Э.Ч. Петрофизика: теория и практика изучения коллекторских свойств горных пород и движения пластовых флюидов: пер. с англ. - М.: Премиум Инжиниринг, 2009. - $868 \mathrm{c}$.

7. Houze O., Viturat D., Fjaere O.S. Dinamic data analysis. - Paris: Kappa Engineering, 2008. - 694 p.

8. Warren J.E., Root P.J. The behavior of naturally fractured reservoirs // Soc. Petrol. Eng. J. - 1963. Vol. 3, is. 3. - P. 245-255. DOI: 10.2118/426-PA.

9. Tiab D. Modern core analysis. Vol. 1. Theory, core laboratories. - Houston, Texas, 1993. - 200 p.

10. Van Golf-Racht T.D. Fundamentals of fractured reservoir engeneering / Elsevier scientific publishing company. - Amsterdam - Oxford New York, 1982. - 709 p.

11. Horne R.N. Modern well test analysis: A computer Aided Approach. - 2nd ed. - Palo Alto:

Petroway Inc, 2006. - 257 p.
12. Определение параметров трещиноватости пород на основе комплексного анализа данных изучения керна, гидродинамических и геофизических исследований скважин / С.С. Черепанов, И.Н. Пономарева, А.А. Ерофеев, С.В. Галкин // Нефтяное хозяйство. - 2014. № 2. - C. 94-96.

13. Johnson N.L., Leone F.C. Statistics and experimental design. - New York - London Sydney - Toronto, 1977. - 606 p.

14. Путилов И.С. Разработка технологий комплексного изучения геологического строения и размещения месторождений нефти и газа. Пермь: Изд-во Перм. нац. исслед. политехн. ун-та, 2014. - 285 с.

15. Путилов И.С., Галкин В.И. Применение вероятностного статистического анализа для изучения фациальной зональности турнефаменского карбонатного комплекса Сибирского месторождения // Нефтяное хозяйство. 2007. - № 9. - C. 112-114.

Please cite this article in English as:

Galkin V.I., Ponomareva I.N., Repina V.A. Study of oil recovery from reservoirs of different void types with use of multidimensional statistical analysis. Bulletin of PNRPU. Geology. Oil \& Gas Engineering \& Mining, 2016, vol.15, no. 19, pp.145-154. DOI: 10.15593/2224-9923/2016.19.5

Просьба ссылаться на эту статью в русскоязычных источниках следующим образом:

Галкин В.И., Пономарева И.Н., Репина В.А. Исследование процесса нефтеизвлечения в коллекторах различного типа пустотности с использованием многомерного статистического анализа // Вестник Пермского национального исследовательского политехнического университета. Геология. Нефтегазовое и горное дело. - 2016. - Т.15, №19. - C.145-154. DOI: 10.15593/2224-9923/2016.19.5 